\title{
Inability of Crossing Borders: Csaba Székely's Bányavidék [Mine District] Trilogy
}

\author{
Boróka PROHÁSZKA-RÁD \\ Sapientia Hungarian University of Transylvania (Cluj-Napoca, Romania) \\ Department of Humanities \\ prohaszkaboroka@uni.sapientia.ro \\ Ingrid TOMONICSKA \\ Sapientia Hungarian University of Transylvania (Cluj-Napoca, Romania) \\ Department of Humanities \\ tomonicskaingrid@uni.sapientia.ro
}

\begin{abstract}
There are countless ways of crossing borders, be they physical, geographic, social, economic, cultural or psychological. When coming up against a border, one has two options: either to cross it or to remain within. This essay investigates Csaba Székely’s Bányavidék [Mine District] trilogy primarily from the perspective of such concepts of imagology as region, center-periphery dichotomy, identity, image, representation, as well as stereotypes and clichés, and examines whether the playwright truly deconstructs such stereotyped representations of the specific geographical and cultural space and its people the trilogy focuses on.
\end{abstract}

Keywords. Csaba Székely, Bányavidék [Mine District], Szeklerland, stereotypes.

\section{Introduction}

Csaba Székely made his name in literary circles first with his short fiction published in various journals and magazines. However, his big breakthrough came in the field of drama when he won the 2009 BBC World Service/British Council's International Playwriting Competition with his English-language radio play Do You Like Banana, Comrades?. The Hungarian speaking public though only really got acquainted with the young playwright in 2011 when Bányavirág [Mine Flower] - one of the award-winning plays of a student playwriting competition - was first performed and then published in the literary magazine Látó. And upon the immediate success of the play, both with audiences and 
critics, Székely continued writing about the same group of characters, the same region and the same topics till the work grew into the trilogy Bányavidék [Mine District] - encompassing also Bányavakság [Mine Blindness] (2012) and Bányavíz [Mine Water] (2013). ${ }^{1}$ Asked whether initially he had in mind writing a trilogy, the playwright said that at the time it seemed a singular exercise, but that during the creative process of writing [Mine Flower] he realized that he had a lot more to say about the topic (Csicsely 2012).

Reviewers and theatre critics seem also to have had a lot to say about Székely's trilogy; much less so the academics in the sense that up to the present we have no knowledge of any scholarly articles or studies having been published about the plays. Our aim, however, is not primarily to fill that gap; much rather, in the context of the wider topic of crossing borders and transgressing boundaries, we argue that, similarly to the characters of the trilogy unable to cross any borders, the playwright himself proves unable to cross certain borders, despite his desire to break taboos and deconstruct stereotyped images and representations of Transylvania and its inhabitants, and specifically Szeklerland and the Szeklers. ${ }^{2}$ We argue that his attempt at contouring a specific geographic, social, economic, cultural and psychological space results in not only his characters being trapped in this environment, but the playwright himself remaining stuck with stereotypes and clichés, offering a different though still unilateral representation of a complex milieu. ${ }^{3}$ Thus, his goal of deconstructing the stereotyped image of Szeklerland remains - at least, partially - unfulfilled; what is more, he offers a representation that itself reproduces and perpetuates stereotypes.

In our investigation we rely on concepts of imagology and have employed the analytic tools offered by Manfred Beller and Joep Leerssen and their useful definitions of terms such as territory, region, center and periphery, identity, image, representation, as well as prejudice, stereotype and cliché.

1 To our knowledge, at present there exists no official translation into English of the plays. All titles used in the essay are our translations. Similarly, quotations from texts not available in English - from the plays, reviews, interviews, or specialized literature - are our own. For the sake of fluency from here on we use only the English titles of the plays.

2 Szeklerland is a particular historical and cultural region of Romania, formerly part of Hungary, populated in majority by Hungarians. Szeklers ("székely" in Hungarian) are considered and consider themselves a particular ethnic group among Hungarians, the biggest part of the largest minority in Romania (Horváth 2010, 147).

3 Different in the sense that so far dramatic representations of the Szeklerland and of Transylvania have been built on the positive image of this space. Such classical Szekler-Hungarian writers as Áron Tamási, András Sütő, Géza Páskándi, János Székely or more recently András Visky have created nuanced images of human fate and political, economic and cultural circumstances in this region in a carefully elaborated dramatic form. For a selection of Hungarian plays from Transylvania in English translation, see Silenced Voices. Hungarian Plays from Transylvania selected and translated by Csilla Bertha and Donald E. Morse. 


\section{The Trilogy and Its Reception}

The [Mine District] trilogy takes audiences and readers to a rural milieu, an unidentified village somewhere in Szeklerland - unnamed, thus in a sense universalized, or rather generalized for the whole Szekler region - with all its inhabitants trapped in the despair of alcoholism, theft and sexual perversion, of lies and suicide. This is a world defined by its limits and limitations. In [Mine Flower] a dying (off-stage) father has been doing nothing for the last two years but ordering his two grown-up children - Iván and Ilonka - around. People come and go in the house, mostly coming for a free drink, and they talk about nothing but the misery of their lives, their inability to leave or the impossibility of leaving and the only solution they see is hanging themselves. [Mine Blindness] focuses on the confrontation between Ince and Izsák, both of them candidates for the village mayor's office. Ince, who has been mayor for many years now, calls in a Romanian policeman (Florin) to have his opponent arrested, despite himself being the biggest thief in what concerns the forests of the village. While the first play of the trilogy addresses familial and interpersonal relations, the second attempts a depiction of interethnic relations as well. The third, [Mine Water] reaches the depths of perversion, its protagonist being the homosexual pedophile Catholic priest of the village, whose house seems a representation of a second Gomorrah on Earth. And there is no respite and repose, all three plays are structured with a fast-pace dialogue in a language (all of the characters speaking in the same manner and with the same vocabulary) that - many would consider - unprintable. ${ }^{4}$

Székely's trilogy in fact grew out of an MA workshop where students were asked to rewrite a classic play and Székely's choice fell on Chekhov's Uncle Vanya. In an interview given to the theatrical blog vanyabacsi.blog.hu, among further literary models that inspired and influenced him, Székely also lists Martin McDonagh's The Cripple of Inishmaan. Reading the plays one also necessarily thinks of Eugene O'Neill's The Iceman Cometh with its characters trapped in Harry Hope's bar, as if stuck in time and place with their illusions and delusions of leaving and leading successful lives somewhere else; something that also turns up in the minds of Székely's similarly trapped characters. And, of course, the multiple dialogues where characters seem to talk next to each other rather than to each other, the multiple instances where - though they are constantly talking - the characters' interactions are nothing but examples of the breakdown of meaningful communication, the total stasis of the village with nothing and no one ever changing nod towards existentialism and the theatre of the absurd, including Beckett, Ionesco, Pinter, or from the Hungarian theatrical tradition Örkény.

4 Among the multiple reviews, articles and interviews, one of the very few critical ones is Lajos Szakolczay's (2014) book review upon the publication of the trilogy that also addresses the trilogy from the perspective of dramaturgy, diction and character-treatment. 
[Mine Flower], and later the other two plays of the trilogy have gained resounding success for their author. They have been put on numerous times by both professional and amateur theatre groups, including the Hungarian National Theatre. And they have brought the playwright a number of prizes and acclaim, and - surprisingly - a lot of success not only with critics and other professionals of the theatrical world, but also audiences, including those from Szeklerland. The explanation of such success could rely in the antithesis between the image of Szeklerland and the Szeklers promoted in Hungary and also in Transylvania and the one created by Székely. There exists a stereotypical representation of Szeklerland created and propagated by the Other - in this case primarily Hungarians from Hungary, a representation that largely influences and often stands as the basis of the Szeklers' self-image. And Székely's aim was to destroy this idealized image, arguing that he merely mirrored reality at is was. In an interview, asked whether the depicted world was a typical Transylvanian one, he specified: "We are also like that, these stories are a slice of what we witness in our environment," stating that this was the way he saw people from Transylvania, and in larger terms from Eastern Europe, stipulating that there were regions in Europe where people lived similar lives to those led by the characters of the trilogy and that his goal was to draw attention to this fact as well (Szilléry 2013).

According to sociologist Margit Feischmidt, there exist two images of Transylvania in Hungary which are not only different, but more than that, they contradict each other. There exists, on the one hand, a Transylvania that "resembles us, what is more, it is identical with us, Hungarians" $(2005,7)$, maybe even "more Hungarian" than any region of Hungary. Thus, it is a cultic space where ancient, authentic Hungarian culture is maintained. On the other hand, Transylvania is also seen as a distant, different, other, foreign land that is backward, less modernized, moreover, uncivilized; still, a positive image in the sense that Transylvania here becomes a synonym for the idealized rural setting, close-to-nature lifestyle and community-based society $(2005,7)$. Of course, Feischmidt states, both of these images are constructs, and far from experienced reality $(2005,7)$. Their legitimacy consists in the spaces they themselves create through discourse.

With reference to the Szeklers' self-image and autostereotypes sociologists state that they have arisen through the natural course of transition across political borders of heterostereotypes existing in Hungary. Similarly to Feischmidt, researchers Alpár Horváth and Gábor Michalkó also maintain that the Szeklers have adopted the image formed in Hungary about themselves. They add that Hungarians from Hungary - and, consequently, also the Szeklers themselves consider that the Szeklers have the sacred responsibility to resist any assimilatory politics or globalizing pressure, any urge to leave, and must remain in the space

The translations from Hungarian specialist literature are our own throughout the article. 
they were born in $(2014,154)$. Just like the representation of Szeklerland as a fundamentally rural, close-to-nature realm, unspoiled and uncorrupted by global trends, this image of the Szeklers as the guardians of this space and of authentic Hungarian culture has by now become a cliché.

\section{Imagological Concepts and the Trilogy}

\subsection{Identity, Image, Representation}

'Identity [...] involves the meaning of 'being identifiable,' and it is closely linked to the idea of permanence through time. [...] [H]owever, this older and deeper, diachronic meaning of the notion of identity has become overshadowed by the more current, synchronic meaning of a 'separate and autonomous individuality,", Leerssen argues $(2007,335)$. Accordingly, the diachronic dimension of identity means that someone or something remains identical with itself/him/herself, that there exists something static and unchanging in us, and it also involves the belief that the past ceases to become the past, it persists through time and constitutes the core of our image about ourselves - be it individual or group identity we are speaking about. The synchronic meaning, however, implies a self-definition on the basis of contrast and comparison with the Other and the notions of the autonomy and self-awareness of the subject. In this sense, then, identity is not a fixed entity, despite its diachronic dimension; much rather, it may be perceived as a position shifting due to one's relations to the non-I, something that we construct. As Leerssen further states, alterity, the other, the foreign is constitutive of identity, which itself is not a given, but much rather it is in constant becoming in the course of conceptualization and articulation.

Group identity is also a process rather than a state, "a balancing process where the internal cohesion and external distinctness of the group overweigh the group's internal diversity and its external similarities" (Leerssen 2007, 337). Group identity's foundation lies then on the presumption that - though multivocal and diverse - the group has a homogenous core. This undifferentiated core is presupposed to be detectable mostly in small-scale rural communities. To use Leerssen's words, such atom-units are nothing but fata morgana $(2007,338)$, mental constructs in the form of images.

Similarly, our opinion of others and, implicitly, of ourselves is based on images. Images are the discursive representations of the self and of the group, and thus they change and shift depending on the context, age, intention, communicative situation, etc. The verbalization of these images - of the self, of others, of our environment - has always been the main preoccupation of the arts, of literature conceiving its task as the "representation" of some external or internal reality. 
As Ann Rigney argues, representation “[a]s a category of cultural analysis, [...] has become the preferred term to designate the ways in which texts [...] provide images of the world" $(2007,415)$. This "mirror" function of the arts and of literature, however, has always been a problematic issue both ontologically and epistemologically, and has by the early twentieth century become refuted, if it has ever been truly and universally accepted. Representations construct the world rather than reflecting it; according to Rigney "they are ways of constructing and directing our view of the world with the help of language” $(2007,415)$.

\subsection{Territory, Region, Periphery}

We construct, conceive and verbalize our identities relying on and with the use of multiple concepts and in contrast to the image we have formed about the Other. One of these constitutive elements is space, or territory, specifically the concept or image of the homeland. Social sciences and cultural studies, though, have pointed out that recently space and position have tended to lose their defining quality in what concerns identity construction and that there have been detectable beginnings of an ongoing global deterritorialization process. ${ }^{6}$ However, it has also been shown that there is now a conscious counter-action towards reterritorialization. Due to political, economic, social, etc. reasons (mainly political) efforts have been made to refill the space emptied of its symbolic significance with symbolic valences of value. We witness a ritual reoccupation of space in the hope that renewed territorial attachment would counterbalance emigration and would offer a new sense of an anchored, thus stable identity. ${ }^{7}$

Such reterritorialization is often attempted at the regional or local level, in such small-scale micro-regions as villages, mainly because these micro-regions

6 See, for example, Gilles Deleuze and Félix Guattari Anti-Oedipus (1977); Anthony Giddens The Consequences of Modernity (1990); Arjun Appadurai "Disjuncture and Difference in the Global Cultural Economy" (1990); John Tomlinson Globalization and Culture (1999); Gil-Manuel Hernàndez i Martí "The Deterritorialization of Cultural Heritage in a Globalized Modernity" (2006); Noel B. Salazar and Alan Smart “Anthropological Takes on (Im)Mobility” (2011), etc.

7 Investigating specific aspects of interethnic relations and their media-representation in Szeklerland, Bíborka Ádám writes: "As a result of historical and social changes of the last decades, ethnicity research, the study of ethnic and/or cultural identity and of categories of interethnic relations, the exploration of their representation have become central issues of sociological discourse. Primarily as an effect of theories coming from Western Europe and the overseas, the study of phenomena denoted through the above mentioned terms has unfolded with special intensity in Central- and Eastern Europe. All these can, of course, be correlated with the fall of political systems with decades-long traditions, of socialism and communism, whose fall has initiated the process of self-definition, identity articulation of ethnic groups living in these countries, as well as the processes of redistribution of border territories, symbolic spaces and goods. Thus, a new process has officially started in the lives of Central-Eastern-European nations, through which these given nations and groups redefine themselves, their past, their present and their relations to their neighbor or co-existing nationalities” $(2016,9)$. 
are generally viewed as ideal for such reloading of space as these are thought to be the locations of sustained traditions and an "unspoiled" and "uncorrupted" pastoral connection to nature and to stereotyped images of rural wisdom and authenticity. Relying on Sengle's arguments Leerssen states:

Following Romanticism, the rustic tale became a cult all over Europe. Urbanization and industrialization provoked as a counterreaction a nostalgic celebration of the simplicity, traditions and artless spontaneity of the preindustrial, pre-modern countryside. In the climate of the modernizing state, a need was obviously felt for a more affective focus of loyalty, one involving childhood memories, family history and communitarian ties rather than citizenship and institutional bonds. The rustic community had become peripheral to the modern state, but in affective terms retained an important status: even if one did not have direct, personal connections with the rustic countryside, with a 'homeland,' one vicariously projected oneself into it. $(2007,412)$

This nostalgic image of the village is built on representations of it that single out and emphasize such aspects of small-scale community life as stasis, both in the sense of staying and in the sense of social immobility, intimate relations among members of the community who, though they may have little education, possess an innate or inherited wisdom and common sense that urban society seems to have lost, and "a high degree of solidarity and no loneliness" (Leerssen 2007, 413).

In this context the village becomes the counterpart of the state or of larger cities in the center-periphery dichotomy. Despite the fact that they may be differently valorized, either one or the other being seen as the positive pole, the center is always perceived as the locus of power, while the periphery as outside of the network of power. Similarly, the center is in constant movement, development and change, while the periphery is fundamentally static. Leerssen also identifies a temporal dissociation between them: the periphery always figures as backward, stuck in some past era - of either barbarism or a noble and innocent but still savage state, "bound up in timeless traditions" $(2007,208)$.

The idealized, pastoral image and representation of the periphery/village echoes what Michel Foucault calls a heterotopia, a space endowed with special features representing utopias, authenticity, where even our perception of time is altered. As Zsolt Szíjártó phrases it, "as spaces of continuity in the continuously - and extremely rapidly - changing social and cultural environment, they [heterotopias] suggest a certain type of timelessness, of them being out of time, and they follow and offer the models of permanence, reliability and the validity of traditions" $(2000,10)$. 


\subsection{Prejudice, Stereotype, Cliché}

Similarly to the way representations shape and construct our perceptions of the world and of ourselves and others, prejudices are at the foundation of our perceptions. As Hans-Georg Gadamer, defending prejudice, argues, people construct their perception of reality on the basis of prejudices, much rather than facts, reason, judgment (1989). From the perspective of imagology, however, Beller understands prejudice as a "key concept for any preconceived and unsupported opinion and attitude that influence[s] our perception, description and judgement of others" $(2007,404)$. Accordingly, prejudice is always already in "information deficit" (Leerssen 2007), given that it is built through the process of singling out certain characteristics from a relatively infinite cluster and excluding/totally neglecting and disregarding others. These singled out characteristics then will be amplified and emphasized, usually with the purpose of criticizing others, and thus heightening our own value.

And though the terms stereotype and cliché are often used as perfect synonyms of the term prejudice, Beller offers a clear definition of all three and differentiates them as follows: “'prejudice' [...] [is] a moral judgement or attitude, stereotype [...] [is] that attitude's fixed expression, and cliché [...] [is] a stylistic turn of phrase" $(2007,404)$. In other words, stereotypes verbalize prejudices, and as discursive practices they themselves will also necessarily distort reality. According to Aronson's definition: “[a] stereotype is a generalization about a group of people in which incidental characteristics are assigned to virtually all members of the group/regardless of actual variation among the members. Once formed, stereotypes are resistant to change on the basis of new information" $(2005,434)$. Stereotypes, then, are overgeneralizing statements that are also static and rigid, and their relationship to reality constitutes a problematic issue. Clichés have an even more controversial relation to the experienced world given that they have practically no relation to reality, but are rhetorical forms. As Beller argues, unlike stereotypes that contain valorizing aspects be they positive or negative, clichés are "formulaic generalizations which have no basis in empirical experience, not any serious purpose as a moral judgement" $(2007,297)$.

\section{The Trilogy - Stereotypes Deconstructed or Reiterated?}

As previously argued, there exists a stereotyped image about Transylvania, and specifically Szeklerland as a location that - though a periphery, thus to a certain extent backward and outside of the network of power/or maybe exactly because of this - holds and sustains authentic, ancient Hungarian culture, an idyllic 
space of intimacy, comradery, ancient wisdom and close-to-nature lifestyle, a predominantly rural area populated by people aware of their role as the preservers of traditions. Referring to such an idyllic image of Szeklerland and responding to the accusation that the trilogy destroys this image, Székely contends that:

I do not have an idyllic or a non-idyllic image of Transylvania, I present what I see. In spite of the fact that these are very local stories, Transylvanian people, Transylvanian places, and I like being a Transylvanian writer, after a while this aspect will vanish and in these texts the Transylvanian-ness of people is going to lose its importance, leaving behind only people, as the country separates itself from the characters of the Chekhov plays. To have a universal message, this is my goal. (2013)

The overwhelming majority of reviews emphasize that Székely is a breath of fresh air precisely due to the fact that he discards the idealized image of Szeklerland by addressing taboo topics such as unemployment, Hungarian-Romanian relations, pedophilia, corruption, etc. ${ }^{8}$ As the dramatist Zsuzsa Radnóti argues, his works negate traditions to such an extent that he becomes a "tradition-maker" himself, putting an end to the image of the Sweet Transylvania in dramatic literature (qtd. in Kovács 2013). She sustains her argument with a citation from [Mine Flower]: "The only tradition we keep here is that of drinking [...] we drink ourselves to the ground, we jump at each other's throats, and afterwards we go steel some wood from the forest. This is our big fucking tradition" (qtd. in Kovács 2013). And Székely himself, when asked about the reaction of audiences who live in the region where the trilogy is set, has stated: "Last year, after a performance, an elderly man [...], who found the play very entertaining and significant, said: 'unfortunately, this is how we live"' (Szilléri 2013, emphasis added).

Deconstruction of stereotypes is only possible by either pushing them to the extreme and thus tipping the representation over to the absurd, or by eliminating them through nuancing the image. Replacing them with others does not resolve the initial problem; what is more, such replacement carries the risk of sustaining stereotypical thinking and representation. In our reading, Székely's trilogy does exactly that, namely it replaces a set of (relatively) positive stereotypes with a cluster of negative ones.

In the [Mine District] trilogy Székely then intends to create a representation of Szeklerland and its inhabitants that would replace or at least shade the idealized stereotypical heterostereotypia created in Hungary about this region that has also become an autostereotypical image adopted, internalized and now propagated by Szeklers themselves. All three plays are set in the same unidentified, thus generalized village somewhere in Szeklerland. And though it retains some of

8 See, for example, reviews by Gábor Ménesi (2013) or Bálint Kovács (2013). 
the characteristics of the Romantic image of Leerssen's argument quoted above, it becomes a counter-image of the positively valorized rural location: it is static, even time seems to stand still here, with absolutely no social mobility, where everyone knows everyone else intimately but this intimacy offers grounds for mocking, using and misusing each other rather than functioning as a remedy for loneliness. This is the periphery par excellence, stuck in time, backward, passive, violent, almost barbaric. Its symbolic valences that would link people to this place and would offer them grounds for identity-construction on the basis of connection to the homeland are ridiculed; it is a space emptied of real value other than the forests that can be stolen. In this sense, then, the plays illustrate a process of deterritorialization: the characters have lost their attachment to the land of their forefathers. Efforts of reterritorialization are also mocked: for example, at the end of [Mine Flower] the camera crew that has come to the village tries in vein to highlight the natural and cultural values of the region, the interviewees respond in mere clichés. They perceive the village as a prison, a space that robs them of their free will and traps them in its inertia.

In these plays the center in the center-periphery dichotomy is also negatively valorized. Though some of the characters dream and talk about leaving the village, they have no reliable knowledge of the outside world. Still, they want to escape this stasis and go somewhere else - to work in Italy, or to Kolozsvár (Cluj-Napoca), to a city where they would be praised and loved, as the doctor from [Mine Flower] hopes. For here, in the village the only way to fit in is either through drinking heavily or through hanging oneself, which in his drunken stupor the doctor contemplates doing. These hopes and dreams, however, have no foundation: villagers do not even possess a constructed image of the center, they just know that it must be different, other than what they experience in their own environment.

The city, when it appears, becomes a place of corruption, decline and death as well. Florin, the city policeman's wife in [Mine Blindness] died a grotesque death when her head was cut off by a tram (reminiscent of Bulgakov), while in the same play Izabella, the mayor's daughter gets into trouble in the city because her roommates grow cannabis on their balcony. Her fate also shows how the center does not necessarily guarantee the fulfillment of dreams: she has been there for the last decade and though her father keeps financing her "studies" at the university where one has to pay off professors to make it to graduation and, as she promises, become mayor herself one day - we learn that she left the university three years earlier and has been since working as a cleaning lady in a supermarket.

The cliché of the American dream is also parodied: in [Mine Water] Irén's daughter is supposed to be in America, where no one drinks and a housekeeper or a teacher earns one million dollars. But in fact she did not go any further than the neighboring village where she eventually committed suicide; thus Irén waits in vain for her to return. And in case anyone returns from some center due 
to some familial obligation, like Ilonka, Iván's sister does in [Mine Flower], the village immediately turns into a prison where she becomes invisible and inert.

If the setting of the plays is totally static, so are the characters populating it. We meet drunken villagers, a disillusioned and burned-out doctor, a corrupt mayor, a perverse pedophile Catholic priest, a narrow-minded teacher outraged not because a man made his sixteen-year-old daughter touch him in exchange for candy but because he was a protestant, and so on. Female characters are also trapped in this world of drinking, disillusionment and brutality, where they are either rendered invisible (Ilonka in [Mine Flower] complains that nobody sees her), or considered nothing but prey that has to be hunted down. And women themselves tend to submit to this image: in [Mine Flower] Iván's neighbor, Irma wished for nothing more than to be Iván's trophy. She is certain that she would be able to dig beyond Iván's rough surface and find there the "hidden mine flowers." But, of course, despite the unexpected opportunity their relationship gets once Irma's husband hangs himself, they remain stuck in their condition and the "mine flowers" buried under brutality, violence and despair.

In the trilogy we encounter no dynamic character, which is not surprising taking into consideration that all of them are constructed out of stereotypes and clichés: every Szekler has a knife or an ax/chainsaw used primarily for fighting, every priest has a lover, everyone has a tendency to commit suicide and all of them drink. The only sober grown-up is Iván's neighbor, Illés in [Mine Flower], who eventually hangs himself, towards whom the villagers' attitude is best phrased by Iván: "If only you would drink, like any normal person!” $(2013,157)$. They visit each other in hopes of a free drink, they gather at funerals for the same reason where even the priest is so drunk that he does not even remember who the deceased person is. The Romanian policeman, Florin from [Mine Blindness] also drinks heavily and still jokes about the Szeklers' drinking habits: "Two Szeklers pass the tavern" he says and when Ince asks him to carry on, he responds: "There's no more. That's the joke" $(2013,231)$.

Religion, profession and ethnicity serve only as grounds for further stereotyping and clichés. The only Romanian character in the trilogy is Florin the policeman brought in from town by Ince to investigate and discredit his counter-candidate in the local elections. And similar to the Szeklers, this character is also constructed from a cluster of characteristics stereotypically associated with authority figures: shrewd and manipulative, he uses the locals' naivety and narrow-mindedness to hide his own extreme nationalism. As for the diachronic dimension of group identity construction, the persistence of the past and traditions, all three plays abound in irony and sarcasm. [Mine Flower] ends with a television crew having come to the house to interview Iván who, dressed partially in Szekler folk costume and partly in the several-sizes-too-small pullover he has received as a present from Ilonka, his step-sister, says: 
I'm Iván Vajda, fourty-two-year-old citizen. I've lived here for ... more than fourty-two years. My father also lives here [...] My grandfather also lived here, and his grandfather also, though I haven't met him yet. We live. Yes. We are living. We are living, working, and preserving the traditions. [...] We have everything we need as we lead a traditional life, and we are content with the little we have. This is how we live here. We are living. Should I sing? Not yet? Fine then. [...] We love the traditions and the Holy Catholic Church. [...] It's nice to live here because there are these beautiful mountains, and the pine forests, and that shitty little brooklet gurgles so nicely like a stream. [...] Here everything is so nice as a dream. As a dream. This is what we live in. Yes. This. $(2013,192)$

In [Mine Blindness] maintaining traditions means having a map of the onceexistent historical Hungary on the wall and being a member of a traditional Szekler regiment which has absolutely no practical purpose in the twentyfirst century but its gatherings serve as occasions for drinking and reminiscing about some idealized past lifestyle. However, Izsák, the candidate for mayor, an ardent protector of traditions who fills in even official forms with the traditional Szekler alphabet, eventually leaves the regiment because the group has become too "liberal" to appropriately represent their ethnic and historical belonging to the place. In [Mine Water] the dramatic climax seems to be the point when the teacher's house burns down and the priest hints at it being rebuilt by the closeknit community of the village to which Márton, his foster-son ironically remarks: "One can see a strong sense of community when it comes to drinking others' pálinka"9 $(2013,254)$.

\section{Conclusions}

If stereotypes are verbalizations of prejudices, articulations of our mental images and opinions about others and about ourselves, that means that they constitute a certain type of discourse and can be used to structure narratives. The nature of discourse, however, is that it is structured, while our world, our experiences are chaotic and lack coherence. Thus experience always evades and escapes representation and it cannot be verbalized through stereotypes, considering the rupture between reality and signification.

Székely's attempt to subvert the promoted idealized images fails because reality is, in fact, much more complex than that. Though the playwright claims to have created a representation of another, a/the real mining district, of people populating this region, and claims to deconstruct the false stereotypes of the 
Transylvanian village of pastoral peace, unity of nature and human beings, ancient wisdom and traditions, etc., what the trilogy does is merely to replace one stereotypical representation with another - a negative autostereotype that is just as deficient and false as the one replaced. Despite creating a shocking image and addressing taboo topics, the trilogy remains one-dimensional, built on stereotypes and clichés. In our reading, Székely proves incapable of stepping beyond the usual stereotypical discourse, but simply shows the other side of the same coin. As if a counterimage of the Foucauldian heterotopia, the world of the [Mine District] trilogy is a distressing anti-heterotopia.

A further aspect that shatters the "lifelikeness" and "reality" of the plays is again connected to stereotypical representations. Ton Hoenselaars states when discussing dramatic characters from the perspective of imagology: "assumed traits of stereotypical nature, however minor, seriously tend to problematize the overall texture of established complex, three-dimensional literary character[s]" $(2007,284)$. As demonstrated, all the characters of the trilogy are more or less stock characters, static and one dimensional, from the drunken and disillusioned middle-aged Iván to the corrupt rural doctor, the shrewd policemen, the homosexual Catholic priest to the flighty and irresponsible youth.

And most importantly, as Leerssen argues in his introductory study to Imagology, "the use of national characterizations has undergone an "ironic turn", $(2007,74)$. At the same time, in line with Linda Hutcheon's concept of parody as not only and not primarily mocking, but much rather repeating with a difference and thus honoring and perpetuating the past (1988), Leerssen also warns:

[S]tereotypes and clichés [...] are often invoked ironically [...] with a knowing wink from author to reader. [...] [T] his is part of the multi-leveled playfulness: national characters and stereotypes are not used seriously (as they would have been a century before), but metafictionally, as a game of conventions. By the same token, however, the old stereotypes are perpetuated and given a new lease of life, albeit under the ironic proviso: if they are used half-jokingly, they are also used half-seriously; meant to be recognized, albeit playfully, they nevertheless invoke and perpetuate the currency of the stereotype they avoid taking seriously. (2007, 74-75)

Maybe this "knowing wink" aspect makes Székely's trilogy appealing for some, but for others it remains appalling for it brings into play and perpetuates stereotypes, not idealized images, but the other extreme opposite. And stereotypes, be they positively or negatively valorizing, carry the risk of being taken seriously and accepted and assimilated as truthful representations of the Other or of the self. Unfortunately, this is what we see happening in the case of the [Mine District] trilogy, proven also by the fact that - among many others - for example Noémi 
Herczog states: the Mine Trilogy puts an end to the idealized image of Transylvania and it represents people resembling us (2013, emphasis ours).

\section{Works Cited}

Ádám, Bíborka. 2016. Interetnikus viszonyok reprezentációja háromszéki történelmi emlékünnepségek szerkezetében (2018-2014). [The Representation of Interethnic Relations in the Structure of Historical Anniversaries from Háromszék (1918-2014).] Ph.D. dissertation defended in 2016 at Babeş-Bolyai University, Cluj-Napoca.

Appadurai, Arjun. 1990. "Disjuncture and Difference in the Global Cultural Economy.” In Theory, Culture \& Society vol. 7, no. 2-3: 295-310. http://www. arjunappadurai.org/articles/Appadurai_Disjuncture_and_Difference_in_the_ Global_Cultural_Economy.pdf(Last accessed 05 Oct. 2018)

Aronson, Elliot, Timothy D. Wilson, Robin M. Akert and Samuel R. Sommers. 2005. Social Psychology. London: Pearson.

Beller, Manfred and Joep Leerssen (eds.). 2007. Imagology. The Cultural Construction and Literary Representation of National Characters. A Critical Survey. Amsterdam and New York: Rodopi.

Bertha, Csilla and Donald E. Morse (eds. and trans.). 2008. Silenced Voices. Hungarian Plays from Transylvania. Dublin: Carysfort Press.

Csicsely, Zoltán. 2012. "Poszt - Bányakincsek Székelyföldről.” [“Post - Mine Treasures from Szeklerland.”] In Magyar Teatrum Online [Hungarian Theatrum Online]. http://magyarteatrum.hu/poszt-banyakincsek-szekelyfoldrol/ (Last accessed 05 Oct. 2018)

Deleuze, Gilles and Félix Guattari. 1977. Anti-Oedipus: Capitalism and Schizophrenia. Minneapolis: University of Minnesota Press. https://libcom. org/files/Anti-Oedipus.pdf (Last accessed 05 Oct. 2018)

Feischmidt, Margit. 2005. “A magyar nacionalizmus autenticitás-diskurzusainak szimbolikus térfoglalása Erdélyben.” [“The Symbolic Conquest in Transylvania of Hungarian Nationalism's Authenticity-Discourses.”] In Erdély-(de) konstrukciók [(De)constructions of Transylvania], ed. Margit Feischmidt, 7-32. Budapest and Pécs: Néprajzi Múzeum.

Foucault, Michel. 1971. The Order of Things. New York: Vintage.

Gadamer, Hans-Georg. 1989. Truth and Method. Trans. J. Weinsheimer and D.G. Marshall. London and New York: Continuum.

Giddens, Anthony. 1990. The Consequences of Modernity. Stanford: Stanford University Press. 
Herczog, Noémi. 2013. "Szenteltvizezett bor - Székely Csaba: Bányavíz." ["Wine with Holy Water - Csaba Székely: Mine Water."] http:// magyarnarancs.hu/szinhaz2/szenteltvizezett-bor-szekely-csaba-banyaviz87005/?orderdir=novekvo (Last accessed 10 April 2018)

Hernàndez i Martí, Gil-Manuel. 2006. "The Deterritorialization of Cultural Heritage in a Globalized Modernity." Transfer: Journal of Contemporary Culture no. 1: 92-107. https://llull.cat/IMAGES_175/transfer01-foc04.pdf (Last accessed 05 Oct. 2018)

Hoenselaars, Ton. 2007. "Character (Dramatic)." In Imagology. The Cultural Construction and Literary Representation of National Characters. A Critical Survey, eds. Manfred Beller and Joep Leerssen, 281-284. Amsterdam and New York: Rodopi.

Horváth, Alpár and Gábor Michalkó. 2014. "Az etnicitás turizmus-földrajzi értelmezése erdélyi példákon keresztül.” [“Ethnicity and Tourism Geography: The Case of Transylvania.”] In Földrajzi közlemények [Papers on Geography] no. 138 vol. 2: 150-160.

Hutcheon, Linda. 1988. The Poetics of Postmodernism. History, Theory, Fiction. London: Routledge.

Kovács, Bálint. 2013. "Ez a mi kurva nagy hagyományunk.” [“Our Big Fucking Tradition."] http://egyfelvonas.reblog.hu/ez-a-mi-kurva-nagy-hagyomanyunk (Last accessed 05 Oct. 2018)

McDonagh, Martin. 1998. The Cripple of Inishmaan. New York: Vintage.

Ménesi, Gábor. 2013. "Mint egy méhkas, amit beledobtak a mocsárba." ["Like a Beehive that was Thrown into the Mud."] In Bárka vol. 26, no. 5: 109-111.

O’Neill, Eugene. 1994. The Iceman Cometh. London: Nick Hern Books.

Rigney, Ann. 2007. "Representation." In Imagology. The Cultural Construction and Literary Representation of National Characters. A Critical Survey, eds. Manfred Beller and Joep Leerssen, 415-418. Amsterdam and New York: Rodopi.

Salazar, Noel B. and Alan Smart. 2011. "Anthropological Takes on (Im)Mobility." In Identities: Global Studies in Culture and Power vol. 18, no. 6: 1-8. https:// www.researchgate.net/publication/256439291_Anthropological_Takes_on_ ImMobility (Last accessed 05 Oct. 2018)

Szakolczay, Lajos. 2014. "Székely Csaba: Bányavidék." In Kortárs Online. http:// www.kortarsonline.hu/archivum/2014/09/arch-szekely-csaba-banyavidek. html (Last accessed 01 Oct. 2018)

Székely, Csaba. 2013. Bányavidék. Budapest: Magvető.

Székely, Csaba. 2013. "Amikor nem adok interjút, vicces vagyok." ["When I'm not Giving an Interview, I am Funny.”] Interview with Csaba Székely. 
https://vanyabacsi.blog.hu/2013/09/21/_mindegyik_szereplomben_kucorog_ egy_kis_szekely_csaba (Last accessed 01 Oct. 2018)

Szíjártó, Zsolt. 2000. "A turizmus mint menedék. Képek és elképzelések a Kali medencében." ["The Tourism as an Escape. Images and Fantasies in the Kali Basin]". In Turizmus és kommunikáció [Tourism and Communication], eds. Zoltán Fejes and Zsolt Szíjártó, 7-23. Budapest and Pécs: Néprajzi Múzeum.

Szilléry, Éva. 2013. "Ellenségképeket keresünk magunknak - Interjú Székely Csabával." ["We look for Enemy-Images. Interview with Csaba Székely.”] In Magvető Kiadó. http://kiadok.lira.hu/kiado/magveto/index. php?action=rolunk\&r_id=1684 (Last accessed 10 April 2018)

Tomlinson, John. 1999. Globalization and Culture. Chicago: University of Chicago Press. 